\title{
Assessment of the Availability and Accessibility of Information and Communication Technologies (ICTs) among Scientists of KVKs in Madhya Pradesh and Chhattisgarh
}

\author{
Rohan Sharma ${ }^{1}$, M. M. Patel ${ }^{1}$, Y. D. Mishra ${ }^{2}$ and D. V. Singh ${ }^{3 *}$ \\ ${ }^{1}$ Department of Extension Education, COA, RVSKVV, Gwalior (M.P.), India \\ ${ }^{2}$ Department of Agri. Extn., Directorate of Extension, RVSKVV, Gwalior (M.P.), India \\ ${ }^{3}$ Krishi Vigyan Kendra, Tonk (Raj.), India \\ *Corresponding author
}

\section{A B S T R A C T}

\begin{tabular}{|l|}
\hline Ke y w o r d s \\
Availability, \\
Accessibility, Information \\
and Communication \\
Technology, Krishi \\
Vigyan Kendra
\end{tabular}

Keywords

Availability,

Accessibility, Information

Vigyan Kendra

ICT in agriculture is an emerging field focusing on the enhancement of agricultural and rural development in India. It involves application of innovative ways to use Information \& Communication Technologies (ICT) in the rural domain. The role of Information and Communication Technology (ICT) in the Krishi Vigyan Kendras (KVKs) and research institutions is becoming increasingly prominent because of the potential value of such technologies. ICTs can be used to increase effectiveness and efficiency of extension professional/scientists in KVK. So, in this era of information revolution, the KVK Scientists should be encouraged to use ICTs for different extension activities and field work. In this context a research study was undertaken for 304 scientists working in different KVKs in Madhya Pradesh and Chhattisgarh. The findings of the study indicate that about half $(51.98 \%)$ of the respondents possessed medium level of availability of ICTs, while majority $(56.93 \%)$ of the KVK Scientists possessed medium to high level of accessibility of ICTs.

\section{Introduction}

The traditional agriculture is transforming into hi-tech agriculture and also the need for updated (latest) information is essential for increased agricultural production and productivity, eventually giving a lucrative yield and income to the farming community. The advancements in ICT can be utilized for providing accurate, timely, relevant information and services to the farmers, thereby facilitating an environment for more remunerative agriculture. The important use of
ICT relates to its potential to bring about transformation in agricultural through the enhancement of education and research though the Agricultural Science and Technology Innovation (ASTI) System. Perhaps the most straight-forward way in which this can occur is through the conventional agricultural extension system (May et al., 2007).

Krishi Vigyan Kendra's (KVK) scientists are playing a proactive role in transferring new technology at field level with beneficial 
impacts. They are continuously engaged in improving their professional knowledge and skills by keeping themselves abreast with latest information. Their professional growth and development is enhanced by accruing current information through the use of new information from different source like peers electronic means of communication mainly through professional forums and electronics means of communication through information and communication technology. Information and Communication Technology (ICT) has, in fact, changed the paradigm used in everyday life. Information and Communication Technology provides information about any event-taking place anywhere in the world, at any time, available to any person anywhere in the world at any time.

Keeping these things in mind a study was formulated to know the present status of availability and accessibility of different information and communication technologies among scientists working in different KVKs in Madhya Pradesh and Chhattisgarh.

\section{Materials and Methods}

The study was carried out in Madhya Pradesh and Chhattisgarh State. There are three State Agricultural Universities namely Rajmata Vijayaraje Scindia Krishi Vishwa Vidyalaya (RVSKVV), Gwalior, Jawaharlal Nehru Krishi Vishwa Vidyalaya (JNKVV), Jabalpur in the state of M.P. and Indira Gandhi Krishi Vishwavidyalaya (IGKV), Raipur, in Chhattisgarh state.

There are 47 KVKs comes under the Jurisdiction of SAUs, NGOs and ICAR in MP and $21 \mathrm{KVKs}$ comes under the Jurisdiction of SAUs and NGOs in CG. The study population included all scientists of KVKs of all SAUs, NGOs and ICAR Jurisdiction in both the States. A structured questionnaire was designed based on related literature and objectives of the study and variables and it was send to all scientists of KVKs comes under study area. Validity of the instrument was ensured through a panel of experts. Data was analyzed with Statistical Package for Social Sciences (SPSS) using frequencies, percentages, mean and multiple correlation and regressions.

\section{Results and Discussion}

\section{Availability of Information and Communication Technologies (ICTs) among KVK Scientists}

The results presented in table 1 indicated that Mobile phone (84.16\%), Computer system $(81.68 \%)$, Internet services $(79.21 \%)$, Internet via mobile phone (74.26\%), Landline telephone (69.31\%), Multimedia (64.36\%), Television $(61.88 \%)$ and Multimedia projectors (59.40), were always available with majority of the respondents, whereas Satellite dish $(74.26 \%)$, Tele-center $(69.31 \%)$ and Youtube $(60.40 \%)$ were not available with majority of the respondents. Furthermore Video films were always available with nearly half of the respondents, while e-journals, ebooks, Digital video camera \& player and Video conferencing were available with 32.18 , $30.69,29.70,28$.per cent of the respondents respectively.

The data in table 1 is also revealed that Mobile phone was ranked first according to availability followed by Computer system, Internet services, Internet via mobile phone, Landline telephone, Multimedia, Television, Multimedia projectors, Video films, Video conferencing, Digital video camera \& player, e-books, e-journals, YouTube, Tele-center and Satellite dish.

The overall availability of ICTs among KVK Scientists was studied and results are presented in table 2 . 
A perusal of data in table 2 indicated that about half $(51.98 \%)$ of the respondents possessed medium level of availability of ICTs, while 35.14 per cent possessed high and only 12.87 per cent possessed low level of availability of ICTs.

This finding was in conformity with the findings of Meera et al., (2004) had noted that as a result of the emerging new paradigm of agricultural development, old ways of delivering important services to citizens are being challenged; traditional societies are also being transformed into knowledge societies all over the world, Ovwigho et al., (2009) indicated that modern ICTs such as mobile phone $(98.46 \%)$, video projector $(76.92 \%)$, computer $(73.85 \%)$ and satellite dish $(20.00$ percent) were available to the extension agents in Nigeria and also, Akuegwu et al., (2011) indicated that availability of ICT facilities for quality instructional service delivery in universities in significantly low except internet- connected and desktop computers in Nigeria.

\section{Accessibility of Information and Communication Technologies (ICTs) among KVK Scientists}

The results presented in table 3 indicated that majority of KVK scientists were very much accessible with ICT tools like Mobile phone (79.21\%), Internet services (76.73\%), Computer system (74.26\%), Multimedia $(64.35 \%)$ and Internet via mobile phone $(49.50 \%)$, whereas nearly half of them were very much accessible with ICT tools like landline telephone $(51.98 \%)$, multimedia projectors (47.02\%), television (44.55\%), video conferencing $(44.55 \%)$ and video films (42.08\%).

A perusal of table 3 also revealed that majority of the respondents was not accessible with ICT tools like satellite dish $(59.41 \%)$, Tele- center $(40.60 \%)$ and YouTube. Further the data in table 3 indicated that according to accessibility Mobile phone was ranked first followed by Internet services, Computer system, Multimedia, Internet via mobile phone, Landline telephone, Television, Multimedia projectors, Video films, Video conferencing, Digital video camera \& player, e-books, e-journals, YouTube, Tele-center and Satellite dish which were ranked second, third, fourth, fifth, sixth, seventh, eighth, ninth, tenth, eleventh, twelfth, thirteenth, fourteenth, fifteenth and sixteenth respectively.

The overall accessibility of ICTs among KVK Scientists was studied and results are presented in table 4.

A perusal of data in table 4 indicated that majority $(56.93 \%)$ of the respondents possessed medium level of accessibility of ICTs, while 29.7 per cent possessed high and only 13.36 per cent possessed low level of availability of ICTs. This finding was in conformity with the findings of Olatokun (2007) who reported that computers, printers, Internet, scanners, facsimile, telephones, mobile phones, and photocopiers were accessible for women academics in their institutions, while $11.7 \%$ respondents attested to the fact that videoconferencing facilities were accessible in their institution in Nigeria.

Thus, it can be concluded that majority of KVK scientists had medium to high level of perception towards ICTs.

The possible reason for medium to high level of availability of ICTs could be due to the fact that new technologies can help bring better information services to rural area. In this way, farmers can have much greater control than before over current information channels, to make informed choices. This finding suggests the need to make these modern ICT tools available to KVK scientists. 
Table.1 Distribution of respondents according to availability of ICTs

\begin{tabular}{|c|c|c|c|c|c|c|}
\hline S. No. & ICT Tools & $\begin{array}{c}\text { Always } \\
\text { A vailable }\end{array}$ & $\begin{array}{c}\text { Sometimes } \\
\text { Available }\end{array}$ & $\begin{array}{c}\text { Not } \\
\text { A vailable }\end{array}$ & $\begin{array}{l}\text { Mean } \\
\text { Score }\end{array}$ & Rank \\
\hline 1 & Mobile phone & $170(84.16)$ & $32(15.84)$ & $00(0)$ & 2.84 & I \\
\hline 2 & $\begin{array}{l}\text { Computer } \\
\text { system }\end{array}$ & $165(81.68)$ & $35(17.33)$ & $02(0.99)$ & 2.80 & II \\
\hline 3 & $\begin{array}{l}\text { Internet } \\
\text { services }\end{array}$ & $160(79.21)$ & 35 (17.33) & $07(3.46)$ & 2.75 & III \\
\hline 4 & $\begin{array}{l}\text { Internet via } \\
\text { mobile phone }\end{array}$ & $150(74.26)$ & $40(19.80)$ & $12(5.94)$ & 2.68 & IV \\
\hline 5 & $\begin{array}{l}\text { Landline } \\
\text { telephone }\end{array}$ & $140(69.31)$ & $35(17.33)$ & $27(13.37)$ & 2.55 & V \\
\hline 6 & Multimedia & $130(64.36)$ & $46(22.77)$ & $26(12.87)$ & 2.51 & VI \\
\hline 7 & $\begin{array}{l}\text { Television } \\
\text { with cable }\end{array}$ & $125(61.88)$ & $50(24.75)$ & $27(13.37)$ & 2.48 & VII \\
\hline 8 & $\begin{array}{l}\text { Multimedia } \\
\text { projectors }\end{array}$ & $120(59.40)$ & $50(24.75)$ & $32(15.84)$ & 2.43 & VIII \\
\hline 9 & Video films & $100(49.50)$ & $52(25.74)$ & $50(24.75)$ & 2.24 & IX \\
\hline 10 & $\begin{array}{c}\text { Video } \\
\text { conferencing }\end{array}$ & $85(42.08)$ & $57(28.22)$ & $60(29.70)$ & 2.12 & $\mathrm{X}$ \\
\hline 11 & Digital Camera & $70(34.65)$ & $60(29.70)$ & $72(35.64)$ & 1.99 & XI \\
\hline 12 & e-books & $60(29.70)$ & $62(30.69)$ & $80(39.60)$ & 1.90 & XII \\
\hline 13 & e-journals & $40(19.80)$ & $65(32.18)$ & $97(48.02)$ & 1.71 & XIII \\
\hline 14 & YouTube & $30(14.85)$ & $50(24.75)$ & $122(60.40)$ & 1.54 & XIV \\
\hline 15 & Tele-center & $15(7.42)$ & 47 (23.27) & $140(69.31)$ & 1.52 & $\mathrm{XV}$ \\
\hline 16 & $\begin{array}{c}\text { T V with } \\
\text { Satellite dish }\end{array}$ & $07(3.46)$ & 45 (22.28) & $150(74.26)$ & 1.29 & XVI \\
\hline
\end{tabular}

(Figures in parenthesis indicate percentage)

Table.2 Classification of respondents based on availability of ICTs

$(\mathrm{N}=202)$

\begin{tabular}{|l|c|c|}
\hline \multicolumn{1}{|c|}{ Availability of ICTs } & Frequency & Percentage \\
\hline Low (<29 score) & 26 & 12.87 \\
\hline Medium (29-38 score) & 105 & 51.98 \\
\hline High (>38 score) & 71 & 35.14 \\
\hline
\end{tabular}


Table.3 Distribution of respondents according to accessibility of ICTs

\begin{tabular}{|c|c|c|c|c|c|c|c|c|}
\hline & & & & & & & $(\mathrm{N}=2$ & \\
\hline $\begin{array}{l}\text { S. } \\
\text { No. }\end{array}$ & ICTs & $\begin{array}{c}\text { Very much } \\
\text { accessible }\end{array}$ & $\begin{array}{c}\text { Very } \\
\text { accessible }\end{array}$ & Accessible & $\begin{array}{c}\text { Rarely } \\
\text { accessible }\end{array}$ & $\begin{array}{c}\text { Not } \\
\text { Accessible }\end{array}$ & $\begin{array}{c}\text { Mea } \\
\text { n } \\
\text { Scor } \\
\text { e }\end{array}$ & $\begin{array}{c}\text { Ran } \\
k\end{array}$ \\
\hline 1 & Mobile phone & $160(79.21)$ & $20(9.90)$ & $18(8.91)$ & 03 (1.49) & $01(0.49)$ & 4.65 & I \\
\hline 2 & $\begin{array}{l}\text { Internet } \\
\text { services }\end{array}$ & $155(76.73)$ & $25(12.38)$ & $13(6.44)$ & $08(3.96)$ & $01(0.49)$ & 4.60 & II \\
\hline 3 & $\begin{array}{l}\text { Computer } \\
\text { system }\end{array}$ & $150(74.26)$ & $30(14.85)$ & $15(7.43)$ & $05(2.47)$ & $02(0.99)$ & 4.58 & III \\
\hline 4 & Multimedia & $130(64.35)$ & $40(19.80)$ & $20(9.90)$ & $10(4.95)$ & $02(0.99)$ & 4.41 & IV \\
\hline 5 & $\begin{array}{l}\text { In5ternet via } \\
\text { mobile phone }\end{array}$ & $100(49.50)$ & $55(27.23)$ & $35(17.33)$ & $09(4.45)$ & 03 (1.49) & 4.34 & $\mathbf{V}$ \\
\hline 6 & $\begin{array}{l}\text { Landline } \\
\text { telephone }\end{array}$ & $105(51.98)$ & $45(22.28)$ & $35(17.33)$ & $16(7.92)$ & $01(0.49)$ & 4.17 & VI \\
\hline 7 & $\begin{array}{l}\text { Television } \\
\text { with cable }\end{array}$ & $90(44.55)$ & $55(27.23)$ & $45(22.28)$ & $10(4.95)$ & $02(0.99)$ & 4.09 & VII \\
\hline$\overline{8}$ & $\begin{array}{l}\text { Multimedia } \\
\text { projectors }\end{array}$ & $95(47.02)$ & $45(22.28)$ & $45(22.28)$ & $15(7.43)$ & $02(0.99)$ & 4.06 & $\overline{\text { VII }}$ \\
\hline 9 & Video films & $85(42.08)$ & $65(32.18)$ & $30(14.85)$ & $20(9.90)$ & $02(0.99)$ & 4.04 & $\mathbf{I X}$ \\
\hline 10 & $\begin{array}{c}\text { Video } \\
\text { conferencing }\end{array}$ & $90(44.55)$ & $50(24.75)$ & $40(19.80)$ & $19(9.41)$ & 03 (1.49) & 4.01 & $\bar{X}$ \\
\hline 11 & $\begin{array}{l}\text { Digital } \\
\text { Camera }\end{array}$ & 75 (37.13) & $75(37.13)$ & $25(12.38)$ & $20(9.90)$ & 07 (3.46) & 3.94 & $\mathbf{X I}$ \\
\hline 12 & e-books & $70(34.65)$ & $60(29.70)$ & $45(22.28)$ & $25(12.38)$ & $02(0.99)$ & 3.84 & XII \\
\hline 13 & e-journals & $20(9.90)$ & $40(19.80)$ & $40(19.80)$ & $42(20.8)$ & $60(29.70)$ & 2.79 & XIII \\
\hline 14 & YouTube & $30(14.85)$ & $35(17.33)$ & $45(22.28)$ & 37 (18.31) & $55(27.23)$ & 2.74 & XIV \\
\hline 15 & Tele-center & $10(4.95)$ & $20(9.90)$ & $40(19.80)$ & $50(24.75)$ & $82(40.60)$ & 2.13 & $\mathrm{XV}$ \\
\hline 16 & $\begin{array}{l}\text { T V with } \\
\text { Satellite dish }\end{array}$ & $02(0.99)$ & $15(7.43)$ & 35 (17.33) & $30(14.85)$ & $120(59.41)$ & 1.75 & $\mathbf{X V I}$ \\
\hline
\end{tabular}

(Figures in parenthesis indicate percentage)

Table.4 Distribution of respondents according to accessibility of ICTs

$(\mathrm{N}=202)$

\begin{tabular}{|l|c|c|}
\hline \multicolumn{1}{|c|}{ Accessibility of ICTs } & Frequency & Percentage \\
\hline Low (<39 Score) & 27 & 13.36 \\
\hline Medium (39-67 Score) & 120 & 56.93 \\
\hline High (>67 Score) & 55 & 29.7 \\
\hline
\end{tabular}

If modern ICT facilities are not adequately built into the mainstream of Indian agricultural system, there is likely to be stagnation in the dissemination, utilization and application of scientific agricultural information for purposeful development of the system.

Similarly, in case of accessibility of ICTs majority of the KVK Scientists possessed medium to high level of accessibility of ICTs. 
The possible reason for medium to high level of accessibility of ICTs could be due to the fact that ICT has been a tool for achieving meaningful societal transformation. This transformation is a function of reliable agricultural research network. A network is a group of individuals or institutions linked together because of commitment to collaborate in solving a common agricultural problem(s) and to use existing resources more effectively. The use of ICTs enhance research network in various ways which are facilitated through communication technologies like electronic mail, electronic conferencing, etc. Through these means scientists, administrators and information personnel are provided with rapid and reliable communication while increasing productivity and decreasing communication costs by reducing the physical means of communication channels (Adebayo and Adesope, 2007).

\section{References}

Adebayo, E.L., and Adesope, O.M. (2007). Awareness, Access and Usage of Information and Communication Technologies between Female Researchers and Extensionists, International Journal of Education and
Development using Information and Communication Technology, 3(1):85-93

May, J., Karugia, J., and Ndokweni, M., (2007). Information and Communication Technologies and Agricultural Development in SubSaharan Africa: Transformation and Employment Generation. Final Framework Paper prepared for the African Economic Research Consortium (AERC), 1-47 pages. Retrieved from: http://www.aercafrica.org

Meera, S.N., Jhamtani, A., \& Rao, D.U.M. (2004). Information and Communication Technology in Agricultural Development: A Comparative Analysis of Three Projects from India. Agricultural Research and Extension Network Paper, (135), 20.

Olatokun, W.M., 2007. Availability, Accessibility and Use of ICTS by Nigerian Women Academics. Malaysian Journal of Library \& Information Science, 12(2): 13-33

Ovwigho, B.O., Ifie, P.A., Ajobo, R.T., and Akor, E.I., 2009. The Availability and Use of Information Communication Technologies by Extension Agents in Delta Agricultural Development Project, Delta State Nigeria. J Hum Ecol, 27(3): 185-188.

\section{How to cite this article:}

Rohan Sharma, M. M. Patel, Y. D. Mishra and Singh D. V. 2018. Assessment of the Availability and Accessibility of Information and Communication Technologies (ICTs) among Scientists of KVKs in Madhya Pradesh and Chhattisgarh. Int.J.Curr.Microbiol.App.Sci. 7(08): 4822-4827. doi: https://doi.org/10.20546/ijcmas.2018.708.507 